\title{
TANDA TANGAN ELEKTRONIK DALAM AKTA PERNYATAAN KEPUTUSAN RAPAT UMUM PEMEGANG SAHAM PERSEROAN TERBATAS
}

\author{
Ni Kadek Sofia Arianti, I Nyoman Putu Budiartha, Desak Gde Dwi Arini \\ Fakultas Hukum Universitas Warmadewa, Denpasar - Bali, Indonesia
}

\begin{abstract}
Abstrak
Penelitian ini dilatarbelakangi oleh perkembangan teknologi berperan penting dalam pendirian perusahaan di berbagai daerah di wilayah negara kepulauan yaitu Negara Republik Indonesia, salah satunya adalah Perseroan Terbatas. Penelitian ini bertujuan untuk mengetahui pengaturan tanda tangan elektronik dalam Rapat Umum pemegang Saham Perseroan Terbatas dan mengetahui akibat hukum tanda tangan yang dilakukan secara elektronik dalam akta pernyataan keputusan Rapat Umum Pemegang Saham Perseroan Terbatas. Metode yang digunakan penelitian ini penelitian normatif pendekatannya adalah perundangan-undangan. Kemudian, data yang telah dianalisis disajikan dalam bentuk informal yaitu melalui kata-kata yang dideskripsikan dalam paragraf. Hasil penelitian ini menujukan bahwa pengaturan tanda tangan elektronik dalam akta pernyataan keputusan rapat umum pemegang saham Perseroan Terbatas melalui penelusuran dan ditransformasi menurut terjemahan yang terstruktur dengan berdalih hukum berdasarkan logika bahwa informasi elektronik atau dokumen elektronik dan/atau hasil cetaknya dapat digunakan sebagai salah satu alat bukti hukum yang sah, yang juga merupakan perluasan alat bukti hukum yang sah berdasarkan ketentuan pasal 11 jo. Pasal 5 UU. Oleh karena itu, alat bukti menurut hukum acara di atas yang dibuat dalam bentuk informasi elektronik atau dokumen elektronik, merupakan alat bukti yang sah menurut Undang- undang Informasi dan Transaksi Elektronik, sehingga segala transaksi elektronik yang memanfaatkan media elektronik sehingga menghasilkan tanda tangan elektronik yang dimuat pada akta penetapan hasil putusan RUPS Perseroan Terbatas dapat dianggap sebagai akta. Kemudian, akibat hukum tanda tangan yang dilakukan melaui media elektronik yang hasil penetapan dari RUPS tersebut berdampak hukum terhadap status legalisasi dari akta tersebut yang menurut UU terkait dinyatakan sah sejauh akta tersebut dipandang sebagai akta di bawah tangan.
\end{abstract}

Kata kunci: Pemegang Saham; Perseroan Terbatas; Tanda Tangan Elektronik

\begin{abstract}
This research is motivated by the development of technology playing an important role in the establishment of companies in various regions in the territory of the archipelago, namely the Republic of Indonesia, one of which is a Limited Liability Company. This study aims to determine the arrangement of electronic signatures in the General Meeting of Shareholders of Limited Liability Companies and to find out the legal consequences of the signatures conducted electronically in the deed of decree of the General Meeting of Shareholders of Limited Liability Companies. The method used in this research is the normative research approach is legislation. Then, the data that has been analyzed are presented in an informal form, through the words described in paragraphs. The results of this study address that the regulation of electronic signatures in the deed of the decision of the decision of the general meeting of shareholders of the Limited Liability Company through tracing and transformation according to structured translation by reasoning based on logic that electronic information or electronic documents and / or printouts can be used as evidence legal law, which is also an expansion of legal legal evidence based on the provisions of article 11 jo. Article 5 of the Law. Therefore, the evidence according to the procedural law above made in the form of electronic information or electronic documents, is valid evidence under the Electronic Information and Transaction Law, so that all electronic transactions that utilize electronic media produce electronic signatures that are loaded on the deed of determination of the results of the GMS decision, the Limited Liability Company can be considered as a deed. Then, due to the legal signature that was carried out through electronic media the outcome of the determination of the GMS had a legal impact on the legalization status of the deed which according to the relevant Act was declared valid insofar as the deed was seen as a deed under the hand.
\end{abstract}

Keywords: Shareholders; Electronic Signature; Limited Company 


\section{PENDAHULUAN}

Peradaban manusia jika dilihat dari jaman batu hingga hari ini sangat berubah secara signifikan. Tidak dapat dipungkiri bahwa manusia adalah revolusi dari Homo sapiens. Tak ada keraguan bahwa Homo sapiens adalah spesies paling kuat di dunia. Homo sapiens juga suka berpikir bahwa ia memiliki status moral superior, dan bahwa kehidupan manusia jauh lebih bernilai ketimbang kehidupan makhlukmakhluk lain seperti babi, gajah, atau serigala (Harari, 2015). Hal tersebut telah mengantarkan kita ke dalam suatu era teknologi informasi yang semakin terinovasi yaitu internet. Namun setiap perubahan tersebut harus mampu dijalani ataupun dipelajari agar kelak tidak terjadi masalah karena ditinggalkannya oleh suatu jaman yang begitu canggih, dimana dunia kini memasuki era Revolusi Industri 4.0 yakni menekankan pada pola digital economy, artificial intelligence, big data, robotic, dan lain sebagainya atau dikenal dengan fenomena disruptive innovation (DIKTI, 2018).

Menghadapi tantangan tersebut para penguasa jabatan yang berwenang kini sudah mulai memikirkan cara-cara dan langkah nyata dalam hal menaikan mutu pendidikan dan taraf hidup masyarakat Indonesia khususnya dalam dunia pembisnisan dan usaha untuk mencegah terjadinya suatu musibah karena perjalanan teknologi yang bagaikan angin puting beliung yang mampu membinasakan dalam hitungan detik jika tidak dipersiapkan dengan sumber- sumber yang berbobot manusia unggulan dengan mempelajari segala kemajuan yang ada terhadap perpindahan teknologi sehingga menjadikan dunia ini tembus dari dan ke segala arah tanpa tembok penghalang karena kini dengan mudahnya menggapai suatu informasi dari suatu benua ke benua yang lain. Seperti yang sudah dicanangkan dalam Undang-Undang Dasar Negara Republik Indonesia Tahun 1945, pasal 1 ayat (3) ditentukan bahwa Indonesia adalah sebuah negara kesatuan yang terdiri dari pulau-pulau dari sabang sampai merauke yang berlandaskan hukum. Maka dari itu apapun yang dilakakukan masyarakat Indonesia dalam suatu pembangunan sebuah usaha bisnis diwajibkan untuk memulai dan mengakhirinya sesuai ketentuan hukum Indonesia yang dipandang sangat perlu untuk mendapatkan legalisasi sehingga usaha tersebut dapat berlangsung tanpa harus mendapatkan permasalahan yang berkaitan dengan hukum di Indonesia karena selain memakan banyak biaya disamping itu sangat menyita waktu yang lama karena rumitnya permasalahan hukum di Indonesia jika tidak dilaksanakan sesuai prosedur yang sudah ditetapkan.

Adapun berbagai jenis badan usaha di Indonesia yang dapat dipilih berdasarkan kebutuhan yang menjadi pilihan teratas bergerak dalam dunia usaha pembisnisan. Dalam menjalankan bisnisnya pembisnis memulai dan mengoperasikan usaha mereka dengan bermacam-macam kerangka yang berstruktur hukum, satu dari berbagi macam tersebut yang sering kita jumpai adalah usaha-usaha yang berstruktur hukum Perseroan Terbatas karena lebih nyaman dan lebih jelas pengaturannya. Terdapat kendala bagi atau untuk salah satu pemegang saham yang dimana mengharuskan para pemegang saham untuk hadir dan mengikuti RUPS secara konvensional maka dengan ketetapan yang sudah termuat di dalam ketentuan pasal 77 ayat (1) UU PT merupakan alternatifnya. Berdasarkan ketentuan pasal 1 angka 4 UU PT, RUPS merupakan organ yang memiliki keistimewaan dibandingkan dengan dua organ lainnya.

Di dalam penelitian ini, penulis ingin meneliti lebih jauh terhadap samar- samarnya isi dari ketetapan dalam pasal 16 ayat (1) huruf m Jo. Pasal 15 ayat (3) UU JN-P. Dalam pemaparannya disampaikan bahwa Notaris diperlukan datang secara langsung dan meneken surat ketetapan hasil rapat RUPS didepan semua orang yang menyaksikan pada pasal 16 ayat (1) sedangkan Notaris disebut mempunyai kewenangan lain dalam hal mensertifikasi segala kegiatan yang dilaksanakan dengan bantuan media elektronik terdapat pada penjelasan pasal 15 ayat (3), sehingga dalam pembuatan risalah RUPS yang diselenggarakan dengan melewati perantara elektronik yang diwajibkan untuk menuangkan ke dalam sebuah akta otentik sudah diatur mengenai hal sertifikasi elektronik dalam UU JN-P namun tidak tersirat secara jelas mengenai tanda tangan elektroniknya. Pada akhirnya ketentuan dalam pasal di atas dalam hal pembuatan Akta RUPS yang ditandatangani secara elektronik jika ditinjiau dari UU JN-P dapat ditafsirkan bahwa terdapat suatu kekaburan norma di dalam pasal tersebut yang dapat berakibat Undang-Undang jabatan notaris tidak mampu memberikan jaminan kepastian hukum bagi warga negaranya khususnya bagi para pengusaha yang akan menggunakan jasa notaris untuk membuatkan perjanjian mengenai perseroan terbatas. Berdasarkan deskripsi di atas, penelitian ini bertujuan untuk mengetahui pengaturan tanda tangan elektronik dalam Rapat Umum pemegang Saham Perseroan Terbatas dan mengetahui akibat hukum 
tanda tangan yang dilakukan secara elektronik dalam akta pernyataan keputusan Rapat Umum Pemegang Saham Perseroan Terbatas.

\section{METODE PENELITIAN}

Penelitian ini menggunakan tipe penelitian hukum normatif dengan melakukan pendekatan perundang-undangan dan analisis dalam pendekatan konseptual yang terkait dengan penulisan yang penulis teliti. Materi hukum yang pakai dalam penelitian ini adalah materi hukum primer dan materi hukum sekunder. Adapun proses perangkaian materi-materi hukum melalui cara melisankan atau menelaah bacaan peraturan perundang-undangan dan referensi lainnya yang berhubungan dengan isu penelitian yang penulis bawakan. Bahan-bahan tersebut diolah, ditelaah dan ditransformasi menurut terjemahan yang terstruktur dengan berdalih hukum berdasarkan logika hukum penyimpulan yang sah mulai dari sejumlah hal khusus hingga kesimpulan yang umum yang bersifat boleh jadi atau logis.

\section{HASIL PENELITIAN DAN PEMBAHASAN}

\section{Pengaturan Tanda Tangan Elektronik dalam Rapat Umum Pemegang Saham Perseroan Terbatas}

Bagi mereka pelaksana usaha pembisnisan yang berperan dalam pengoperasian bisnisnya sudah selayaknya wajib mampu untuk menghadapi dan melewati persaingan usaha bisnis yang semakin meningkat dan semakin bervariasi model usahanya sehingga terhindar dari malapetaka gulung tikar karena kebangkrutan jika bisnis yang dijalankan tidak mampu terlaksana karena minimnya kemapuan dalam menghadapi dunia tanpa batas yang sekarang sangat mudah menembus cakrawala dunia pembisnisan tanpa harus berpindah secara langsung ke tempat tujuan. Tetapi tidak banyak namun sudah mulai bisnis-bisnis yang berkembang di Indonesia khususnya sudah menerapkan kekuatan teknologi dan informasi walaupun belum begitu sempurna.

Suatu hal nyata dapat dilihat dan diraba yang memiliki bentuk, ciri khas yang merupakan satu kesatuan pola tersendiri sehingga menjadi ciri terhadap hal tersebut yang menjadi objek. Segala sesuatu yang termasuk dalam kesatuan pola seperti kesatuan informasi yang pasti dan ciri-ciri lain yang bersangkutan dengan suatu kepemilikan pola yang dimaksud menjadi sangat penting. Salah satu kesatuan pola yang memiliki sifat atas suatu pola adalah tanda tangan disebabkan karena tanda tangan merupakan suatu pola unik yang setiap orang memiliki masing-masing pola dari suatu kreativitas yang menjadikan suatu ciri khasnya. Tanda tangan yang diukir dan dikreasikan dengan berbagai rupanya sekaligus merupakan suatu identitas dari seseorang yang melakukannya dan dengan hendak sendiri untuk dijadikan suatu alat pengesah yang sah dan legal. Bukan merupakan hal yang tabu lagi bahwa dalam aktivitas setiap harinya bahwa suatu tanda tangan yang sering disebut sebagai teken dalam hal ini dapat dilakukan dengan memberikan sidik jari yang berfungsi sama sebagai tanda tangan dapat dilakukan karena suatu alasan khusus sehingga seseorang yang hendak melakukan tanda tangan tidak dapat melakukannya selayaknya orang lain lakukan dengan normal. Sidik jari tersebut dapat dipergunakan sebagai pengganti tanda tangan apabila seseorang yang bersangutan memiliki suatu kekurangan dalam tubuhnya seperti mengalami masalah dalam penglihatan (tunanetra) sehingga orang tersebut tidak dapat menggambarkan tanda tangannya dengan sewajarnya. Atau bisa juga dikarenakan mengalami kekurangan pada tubuh lain yang berfungsi membantu dalam penulisan sebuah tanda tangan seperti tangan yang tidak dapat difungsikan dengan normal (kelumpuhan atau matinya saraf pada organ tubuh tertentu) sehingga sidik jari dapat dialokasikan sebagai pengganti tanda tangan yang biasanya orang hawam menyebutnya dengan cap jempol (Kie, 2007).

Keberadaan tanda tangan adalah merepresentasikan adanya suatu tindakan verifikasi dari si penandatangan terhadap apa yang ditandatanganinya, karena penandatangan selayaknya membaca terlebih dahulu dan memeriksa informasi tersebut kemudian membubuhkan identitas dirinya sebagai subyek hukum yang bertanggung jawab atas informasi tersebut (Makarim, 2011). Suatu tanda tangan dapat berupa gambaran atau design yang dibubuhkan dalam suatu pernyataan sebagai tanda persutujuan yang tidak hanya terbatas pada tulisan maupun simbol-simbol yang memiliki ciri khas terhadap karakteristik seseorang, sebagai pengganti penulisan penggantinya dapat dilakukan dengan menempelkan sidik jari yang berupa cap jempol juga dapat dikatakan sebagai tanda persetujuan dalam hal ini disebut tanda tangan, dan berfungsi untuk mengidentifikasi siapa yang melakukan penandatanganan dalam hal ini untuk sebuah pembuktian atas pernyataan yang ditandatangani sehingga dapat diketahui bahwa hal yang ditandatangani berhubungan atau terasosiasi terhadap penandatangannya. 
Ketentuan yang berdasarkan pasal 77 UU PT dalam pelaksanaan RUPS melalui sarana elektronik harus memenuhi paling tidak tiga persyaratan yaitu; 1) peserta rapat harus saling melihat secara langsung, 2) peserta rapat harus saling mendengar secara langsung, dan 3) peserta rapat dapat berpartisipasi dalam jalannya rapat. Jika salah satu syarat tidak terpenuhi RUPS yang dilaksanakan melalui media elektronik yang dimaksud dapat dikatakan tidak memenuhi syarat berdasarkan ketentuan pasal 77 UU PT untuk dijadikan media dalam pelaksanaan RUPS tersebut. Seperti yang dijelaskan oleh Abdulkadil Muhammad, dikatakan bahwa tiap-tiap badan usaha yang berupa perseroan merupakan badan hukum. Dilaksanakan dan dijalankan berdasarkan ketentuan UndangUndang yang dalam hal ini bertindak sebagai subjek hukum yang mengemban seluruh kewajiban dan tanggung jawab dari perseroan tersebut untuk suatu pencapaian yang menjadi tujuan badan hukum itu didirikan dan juga harta kekayaan yang dimiliki sendiri uyang bukan merupakan milik dari organorgan lain yang merupakan kumpulan modal dari para pendirinya (Muhammad, 2010).

Berhubungan dengan pelaksanaannya yang dimana disebut dengan RUPS, yang dalam UU PT merupakan organ tertinggi dalam suatu Perusahaan tidak dapat dipungkiri bahwa para pemegang saham tidak memiliki hak-hak dan kewajiban layaknya Direksi dan komisaris dalam pelaksanaan rapat terkait tersebut. Rapat tersebut hanya dapat diselenggarakan oleh pihak yang terkait dalam hal ini yaitu Direksi karena hak dan wewenanganya yang sudah diatur dalam UU PT pasal 79 ayat (1) baik itu penyelenggaraan RUPS tahunan dan RUPS lainnya harus dilakukan oleh Direksi dengan melakukan pemanggilan terhadap para pemegang saham untuk RUPS. Rapat Umum Pemegang Saham tersebut dapat terselenggarakan apabila RUPS lebih dari $1 / 2$ (satu perdua) bagian dari jumlah seluruh saham dengan hak suara hadir atau diwakili, kecuali Undang-Undang dan atau anggaran dasar menentukan jumlah kuorum yang lebih besar (Binoto, 2012). Bilamana kuorum tidak memungkinkan untuk diselesaikan, maka pemanggilan RUPS yang kedua juga dapat dilakukan untuk menyempurnakan RUPS pertama yang tidak menghasilkan keputusan yang kuorum. Namun dalam pelaksanaan RUPS yang kedua dilaksanakan wajib hukumnya diumumkan bahwa pelaksanaan RUPS yang pertama telah dilaksanakan namun tidak membuahkan hasil sebuah putusan rapat yang kourum. Berdasarkan peraturan yang terkait yaitu UU PT menjelaskan bahwa RUPS yang kedua adalag sah dan juga berhak menarik suatu keputusan apabila dalam RUPS yang paling sedikit 1/3 (satu pertiga) bagian dari jumlah total seluruh saham dengan jumlah hak suara yang datang atau hadir maupun jumlah hak suara karena diwakili tetapi apabila ada perubahan dalam anggaran dasar yang menentukan jumlah kuorum yang lebih besar dari 1/3 (satu pertiga) tersebut. Setelah terlaksananya kuorum RUPS yang kedua namun tetap tidak mampu mencapai putusan yang disepakati semua pihak pemegang saham maka perseroan terkait dapat melakukan permohonan penetapan pelaksanaan RUPS ketiga ke ketua pengadilan negeri di daerah dimana perseroan tersebut berkududukan hukum.

Dalam pemanggilan ketiga juga diwajibkan untuk diumumkan bahwa RUPS kedua telah dilangsungkan karena RUPS pertama tidak dapat tercapai suatu kuorum sehingga perlu dilakukan RUPS ketiga yang akan dilakukan dengan hasil kourum telah ditetapkan oleh ketua pengadilan negeri dimana penetapan yang dilakukan oleh ketua pengadilan negeri tersebut adalah bersifat final dan ingkrah sehingga memiliki kekuatan hukum tetap dan tidak ada lagi RUPS berikutnya.

\section{Akibat Hukum Tanda Tangan yang Dilakukan secara Elektronik dalam Akta Pernyataan Keputusan RUPS}

Kemajuan instrument dalam penggunaan teknologi komunikasi dan transportasi berdampak besar terhadap pemilik saham yang dapat memudahkan dalam perpindahan tanpa harus turun ke lapangan secara langsung dengan cepat dari satu tempat ke tempat yang lain melalui alat teknologi tersebut. Di samping itu peningkatan pada teknologi sekarang yang sangat jauh dari kata buruk kini sudah memasuki batas-batas kecepatan yang terkadang sulit untuk dibayangkan bagi orang-orang yang tidak memahami dunia informasi dan teknologi (IT) ini, memberikan suatu keniscayaan bagi para pemilik saham sehingga mampu membereskan suatu urusan yang menyangkut atau terkait dengan kepentingannya pada suatu perseroan terbatas tanpa harus terjun langsung ke lapangan secara fisik di tempat mana RUPS berlangsung. Dengan mempergunakan Telekonferensi (tele conference) misalnya, pemegang saham dapat mengikuti dan terlibat langsung atau berpartisipasi dalam RUPS dari jarak jauh.

Dari penjelasan ketentuan diatas dapat disimpulkan bahwa 1) pembuatan akta yang dibuat dan disusun sendiri bersifat di bawah tangan yang ditandatangani oleh ketua rapat dan paling sedikit satu 
orang pemegang saham yang ditunjuk oleh peserta rapat,dan 2) pembuatan akta notaris yang bersifat otentik dibuat dan disusun sendiri oleh pejabat umum yaitu notaris tidak diisyaratkan untuk diparaf oleh seluruh komponen pemegang saham, yang dalam prakteknya akta otentik yang dibuat dalam bentuk akta yang belum otentik atau di bawah tangan kemudian dituangkan dalam bentuk akta otentik yang selanjutnya dapat disebut sebagai akta penetapan keputusan Rapat Umum Pemegang Saham. Hal tersebut dapat dikatakan bahwa penandatanganan itu dapat dilakukan baik secara langsung maupun melalui media perantara dimana tanda tangan dilakukan menggunakan fasilitas elektronik. Akta Penetapan hasil dari Rapat dibuat dengan cara memberikan kuasa melaui surat kuasa kepada pimpinan rapat yakni direksi yang merupakan organ tertinggi kedua setelah RUPS dari Perseroan untuk menyatakan keputusan-keputusan hasil dari RUPS tersebut yang telah dilaksanakan oleh para pemegang saham ke dalam Akta Notaris.

Maka dalam pelaksanaan penetapan Akta mengenai hasil-hasil Keputusan Rapat, peserta rapat harus memberikan kuasa kepada pimpinan rapat yaitu Direksi Perseroan untuk menghadap pejabat umum yaitu notaris untuk menyatakan keputusan-keputusan hasil dari RUPS ke dalam Akta Pernyataan keputusan Rapat di hadapan Notaris dimana dalam penghitungan waktu disebutkan paling lambat 30 (tiga puluh) hari setelah pelaksaan RUPS. Sehingga sebelum akta tersebut dirubah menjadi akta otentik yang ditetapkan dan ditandatangani langsung di hadapan notaris akan berdampak pada akibat hukum tanda tangan yang dilakukan secara elektronik dalam akta pernyataan keputusan RUPS tersebut dinyatakan sah sepanjang akta itu dipandang sebagai akta di bawah tangan namun belum dapat dikatakan sebagai akta yang sempurna.

Untuk menyempurnakan akta penetapan hasil rapat tersebut dapat dilakukan seperti yang sudah dipaparkan diatas dengan cara direksi akan dipilih untuk menemui pejabat umum yaitu notaris dalam hal perwakilan terhadap Perseroan yang bersangkutan untuk melaksanakan hak dan kewajibannya untuk mendapatkan tanda tangan dan dilegalkan oleh notaris dimana akta hasil rapat tersebut sudah disetujui oleh para pemegang saham dan terpenuhi sudah persyaratan dalam hal ini Undang-undang yang terkait dalam pelaksanaan tanda tangan elektronik pada pasal 11 UU ITE dan persyaratan pada Undang-Undang yang mengatur tentang PT pada pasal 77 UU PT. Direksi dari perseroan yang berangkutan menuangkan semua hal-hal yang bersangkutan dengan RUPS yang sudah disepakati oleh para pemegang saham ke dalam suatu akta di hadapan notaris di tempat wilayah notaris tersebut berkedudukan dan ditandantangani oleh direksi PT bersangkutan dan juga oleh Notaris sehingga akta tersebut disahkan dan dilegalkan menjadi akta otentik. Sehingga apabila ada permasalahan mengenai RUPS dan pemegang saham, akta yang sudah menjadi akta otentik tersebut dapat dipergunakan sebagai alat pembelaan dan pemecahan suatu permasalahan yang timbul baik di depan pengadilan karena menurut Hukum acara yeng berlaku di Indonesia salah satu alat bukti yang sempurna dalam beracara yaitu akta otentik yang sempurna tanpa cacat ditentukan oleh Peraturan terkait di Indonesia.

Mengenai kewenangan lain dari pejabat umum dalam hal ini yaitu notaris jika ditelaah pada ketentuan perundang-undangan yang terkait UU JN-P pasal 15 ayat (3) diatur mengenai kewenangan lain yang dapat dilakukan oleh notaris, salah satunya disebutkan mengenai kewenangan Notaris dalam hal mensertifikasi transaksi yang menggunakan media elektronik (cyber notary) dipandang belum mampu dioperasikan secara maksimal di wilayah kepulauan Indonesia dikarenakan begitu luasnya negara Republik Indonesia yang terbagi dari pulau-pulau besar dan pulau kecil yang sebagian dari pulau kecil di Indonesia belum terdampak oleh kemajuan teknologi informasi karena masih minimnya sarana penerapan dalam hal penyebaran teknologi tersebut dan masyarakat yang tinggal dan menetap di pulau-pulau kecil yang jauh dari perkotaan masih sangat memerlukan sosialisasi untuk meningkatkan pengetahuan dalam bidang teknologi informasi yang begitu penting dalam mengahadapi era yang serba berkekuatan digital disamping itu juga pemerintahan Indonesia belum mampu mengoperasikan dan memberlakukan Certificate Of Authority (CA) yang merupakan Penyelenggaraan Sertifikat Elektronik karena minimnya sarana dan prasarana dalam penerimaan kekuatan berbasis digital di lapangan oleh masyarakat khususnya para pelaksana usaha-usaha bisnis dan pejabat umum yaitu notaris dalam hal penerapan tanda tangan elektronik.

\section{SIMPULAN DAN SARAN}

\section{Simpulan}

Pengaturan tanda tangan elektronik dalam akta pernyataan keputusan rapat umum pemegang saham Perseroan Terbatas melalui penelusuran dan ditransformasi menurut terjemahan yang terstruktur 
dengan berdalih hukum berdasarkan logika bahwa informasi elektronik atau dokumen elektronik dan/atau hasil cetaknya dapat digunakan sebagai salah satu alat bukti hukum yang sah, yang juga merupakan perluasan alat bukti hukum yang sah berdasarkan ketentuan pasal 11 jo. Pasal 5 UU. Oleh karena itu, alat bukti menurut hukum acara di atas yang dibuat dalam bentuk informasi elektronik atau dokumen elektronik, merupakan alat bukti yang sah menurut Undang- undang Informasi dan Transaksi Elektronik, sehingga segala transaksi elektronik yang memanfaatkan media elektronik sehingga menghasilkan tanda tangan elektronik yang dimuat pada akta penetapan hasil putusan RUPS Perseroan Terbatas dapat dianggap sebagai akta. Kemudian, akibat hukum tanda tangan yang dilakukan melaui media elektronik yang hasil penetapan dari RUPS tersebut berdampak hukum terhadap status legalisasi dari akta tersebut yang menurut UU terkait dinyatakan sah sejauh akta tersebut dipandang sebagai akta di bawah tangan. Dalam proses mengubah status akta penetapan yang masih bersifat di bawah tangan tersebut dapat dilakukan dengan pemilihan seorang yang berkaitan dengan PT tersebut dan memiliki wewenang dalam hal mewakili perusahaan untuk bertindak yaitu Direksi yang sudah mendapat kuasa dari pemegang saham dan paling sedikit satu orang saksi yang ikut dalam pelaksanaan RUPS untuk menghadap pejabat umum yang berwenang dalam pembuatan akta serta legalitasnya untuk menyampaikan hasil dan isi-isi dalam RUPS yang telah disepakati seluruh pelaksana rapat dan pemegang saham untuk dibuatkan ke dalam Akta Otentik yang diwakili oleh Direksi Perseroan Terbatas dengan menghadap langsung di hadapan notaris sehingga hal-hal yang telah disepakati dalam RUPS dituangkan dan ditandatangani secara langsung oleh Direksi beserta saksi beserta notaris di tempat wilayah notaris tersebut berkedudukan sehingga akta tersebut dilegalisasi n ditandatangani dan di cap oleh Notaris maka terciptalah suatu akta penetapan hasil keputusan RUPS yang otentik sehingga dapat dijadikan alat bukti yang sempurna di pengadilan apabila dikemudian hari terjadi permasalahan hukum yang terjadi antar pemegang saham terkait dengan akta RUPS Perseroan yang bersangkutan tersebut.

\section{Saran}

Kepada Pemerintah dalam hal ini yaitu Kementerian Hukum Dan Hak Asasi Manusia yang berwenang dalam penerapan kepastian hukum bagi masyarakat khususnya pelaksana usaha bisnis, diharapkan secepatnya menyiapkan sarana, prasarana yang masih belum diterapkan secara sempurna dan tentunya ditopang dengan penyediaan sumber daya manusia yang bermutu tinggi dalam menghadapi perkembangan sistem elektronik dengan cara memberikan Lisensi kepada badan hukum yang bersangkutan dalm hal itu sebagai lembaga Certification Authority, baik pemerintah maupun swasta, sehingga pengoperasian transaksi elektronik, dengan dokumen elektronik sebagai perjanjian para pelaksana bisnis yang telah diparaf secara elektronik mempunyai kekuatan pembuktian yang sama dengan akta otentik. Selanjutnya, demi keadilan sosial dan kepastian hukum bagi para pelaku usaha khususnya dalam hal pelaksanaan RUPS Perseroan Terbatas dan agar Notaris dapat menjalankan kewenangan mensertifikasi secara elektronik tanpa ragu-ragu, maka segera disempurnakan dan ditegaskan mengenai kewenangan lainnya notaris yang berupa cyber notary pada Pasal 15 Ayat (3) UUJN-P yang belum mampu diterapkan sesuai kebutuhan di dalam melaksanakan suatu RUPS Perseroan Terbatas, khususnya terkait keabsahan dokumen elektronik untuk dijadikan sebagai dasar pembuatan akta autentik.

\section{DAFTAR PUSTAKA}

Binoto, N. (2012). Hukum Perseroan Terbatas. Yogyakarta: Pustaka Yusticia.

DIKTI, S. D. I. \&. (2018). Penjelasan Revolusi Industri 4.0. Retrieved from http://sumberdaya.ristekdikti.go.id/index.php/2018/01/30/era-revolusi- industri-4-0-saatnyagenerasi-millennial-menjadi-dosen-masa- depan/

Harari, Y. N. (2015). Homo Deus: Masa depan Umat Manusia. Tangerang: PT. Pustaka alvabet.

Kie, T. T. (2007). Studi Notariat dan Serba-Serbi Praktek Notaris,. Jakarta: PT. Ichtiar Baru Van Hoeve.

Makarim, E. (2011). Notaris dan Tanda Tangan Elektronik. Cetakan Pertama. Jakarta: PT. Rajawali Grafindo Persada.

Muhammad, A. (2010). Hukum Perusahaan Indonesia (Cetakan Kedua). Bandung: PT. Citra Aditya Bakti. 